FOLIA POMERANAE UNIVERSITATIS TECHNOLOGIAE STETINENSIS

Folia Pomer. Univ. Technol. Stetin., Oeconomica 2017, 335(87)2, 51-62

Tomasz DYCZKOWSKI, Zdzisław KES

\title{
MODELOWANIE DANYCH W TWORZENIU SYMULACYJNEJ GRY BUDŻETOWEJ
}

\section{ECONOMIC DATA MODELLING IN A BUDGET SIMULATION GAME}

Katedra Rachunku Kosztów, Rachunkowości Zarządczej i Controllingu, Uniwersytet Ekonomiczny we Wrocławiu, ul. Komandorska 118/120, 53-345 Wrocław, e-mail: tomasz.dyczkowski@ue.wroc.pl

\begin{abstract}
Summary. The paper analyses problems to be considered when a quantitative model of an enterprise with its manufacturing and sales processes is developed, to serve as an engine for an educational budgeting game. Variables of the model, algorithms which generate data as well as interrelations between user-dependent and user-independent factors are presented. The said factors determine revenue and cost levels in the modelled enterprise. The paper is concluded with results of a simulation which validates accuracy of the model respecting educational goals of management control course, where the budgeting game is going to be used.
\end{abstract}

Słowa kluczowe: controlling, gra budżetowa, model, symulacja.

Key words: management control, budgeting game, model, simulation.

\section{WSTĘP}

Zastosowanie gier w nauczaniu przedmiotów związanych z ekonomią i zarządzaniem nie jest nową koncepcją. Już w latach 60. i 70. XX w. wskazywano na bardziej pozytywne nastawienie studentów do tej formy nauczania niż do tradycyjnych wykładów. Podkreślano również konieczność zrozumienia natury problemu i aktywnego poszukiwania rozwiązań przez graczy, a także interdyscyplinarność wyzwań, których nie da się zastąpić serią zadań (DeCostner i Prater 1973). W rachunkowości gry pojawiły się w sposób naturalny, ponieważ niemal w każdej symulacji biznesowej kluczowymi parametrami są wielkości rachunkowe, w tym przychody i koszty, a podejmowane decyzje wymagają od graczy prowadzenia analiz efektywności na podstawie otrzymywanych raportów. Podkreślano ponadto, że gry wymagają zestawiania różnorodnych informacji w celu podjęcia decyzji; w przyszłej pracy studenci nie zawsze otrzymają informacje uporządkowane tak, aby można je było bezpośrednio wykorzystać w procesie decyzyjnym (Bruns 1965).

Obecnie, gdy gry na komputery osobiste, konsole czy smartfony stały się formą spędzania czasu przez młodzież i dorosłych, należy rozważyć ich włączenie na trwałe do metodyki nauczania zarówno zajęć moderowanych przez prowadzących, jak i w celu stymulowania samodzielnej nauki. Jeżeli jednak gry mają być traktowane jako coś więcej niż edutainment (edukacyjna rozrywka), służący podniesieniu atrakcyjności zajęć, konieczne jest precyzyjne zaprojektowanie i przetestowanie tych narzędzi pod kątem wiedzy, umiejętności i kompetencji, które mają rozwijać na poziomie właściwym dla uczelni. 
W przedstawionym kontekście celem niniejszego opracowania jest sformułowanie i przetestowanie procedury tworzenia modelu przedsiębiorstwa, który może być wykorzystany w komputerowej grze edukacyjnej wspomagającej nauczanie controllingu na uczelni wyższej. Jako wyznacznik poprawności procedury przyjęto to, że stworzony za jej pomocą model prawidłowo odzwierciedla procesy zachodzące w przedsiębiorstwie produkcyjno-handlowym i logiczne relacje między nimi.

\section{MATERIA I METODA}

Zastosowaną w opracowaniu metodą badawczą jest analiza studium przypadku będącego projektem gry działającej na zasadzie symulatora odchyleń budżetowych. Wspomniana gra stanie się integralną częścią nauczania controllingu na studiach licencjackich w ramach kierunku finanse i rachunkowość. Uwaga zostanie skierowana na leżący u podstawy gry model decyzyjny odzwierciedlający sposób funkcjonowania przedsiębiorstwa produkcyjno-handlowego, wraz ze wskazaniem miejsc interakcji studentów z grą. Przedstawione zostaną algorytmy generujące dane, zapewniające realny charakter symulacji, jej właściwą złożoność oraz umożliwiające wielokrotną rozgrywkę dzięki zmienności danych wejściowych. Zostaną też omówione wyniki testów symulujących rozgrywkę z udziałem graczy aktywnych i pasywnych, pozwalające zweryfikować poprawność założeń modelu i ustalić sposób odzwierciedlenia wyników rozgrywki w ocenach studentów uczestniczących w zajęciach.

\section{UWARUNKOWANIA WYKORZYSTANIA GIER BIZNESOWYCH W DYDAKTYCE}

Potencjalnie gry biznesowe mają liczne zalety: pozwalają w atrakcyjny sposób, w krótkim czasie, niskim kosztem oraz bez konsekwencji finansowych przećwiczyć podejmowanie decyzji biznesowych, w tym ryzykownych, na podstawie wiedzy zdobytej podczas tradycyjnych zajęć. Zwolennicy metody twierdzą, że osiągane efekty dydaktyczne są identyczne jak w wypadku sprawdzonych metod nauczania, ale uzyskiwane są w swobodniejszej atmosferze. Przeciwnicy uważają natomiast, że w przypadku bardziej złożonych zagadnień gry nie stymulują pogłębionego zrozumienia problemu (Huang i Hsu 2011). Istnieją jednak przykłady zaawansowanych gier biznesowych, opartych na prowadzonej w czasie rzeczywistym symulacji działalności gospodarczej z wykorzystaniem systemów ERP, które pozwalają zrozumieć i przeprowadzić pełen cykl decyzyjny - od planowania działalności, przez sterowanie zaopatrzeniem, produkcją i sprzedażą, aż po analitykę biznesową. Żródłem sukcesu tych gier jest wysokie pobudzenie studentów do działania przed przystąpieniem do gry i utrzymanie go do końca rozgrywki dzięki rosnącemu rozumieniu procesów biznesowych i satysfakcji z umiejętności radzenia sobie z wyzwaniami (Cronan i in. 2011). Zaletą symulacji budżetowych jest również możliwość doświadczenia niepewności i jej wpływu na podejmowanie decyzji, czego nie można przećwiczyć, analizując problemy z jednoznacznym rozwiązaniem (Michel i in. 2013).

Również na polskim gruncie zwraca się uwagę (Kotapski 2012) na konieczność włączenia do tematyki zajęć laboratoryjnych z controllingu inspirujących zadań, które będą odnosić się do rzeczywistych problemów decyzyjnych przedsiębiorstw i wymagać od studentów samodzielnego 
poszukiwania rozwiązań. Proste i powtarzalne zadania, zamiast wykształcić niezbędne umiejętności i kompetencje, skłaniają raczej do poszukiwań gotowych rozwiązań wypracowanych przez „starszych kolegów” lub w internecie. Jak zauważa Dyczkowska (2012), konfrontowanie studentów ze złożonymi, ale z ciekawymi wyzwaniami przynosi wymierne efekty dydaktyczne, a przygotowane samodzielnie prace zaliczeniowe charakteryzują się złożonością i rzetelnością, prezentując autorskie pomysły rozwiązań problemów gospodarczych, z którymi stykają się przedsiębiorstwa produkcyjne, handlowe, usługowe i instytucje publiczne, jak również menedżerowie konkretnych przedsięwzięć gospodarczych. W ten sposób są kształtowane praktyczne umiejętności niezbędne w zawodowej pracy controllerów.

Projektując symulacje menedżerskie pod kątem ich efektywności dydaktycznej, warto zatem zwrócić uwagę na równowagę 4 czynników: realizmu symulacji, łatwości zrozumienia zasad gry, stymulowania konfliktu celów oraz możliwości zaistnienia konfliktów personalnych w grupie graczy. Realizm symulacji oraz przejrzystość gry są pozytywnie skorelowane z opanowaniem metod rozwiązywania problemów przez uczestników zajęć. Z drugiej strony, realizm symulacji, prowadzący do konkurencyjnych celów lub konfliktów emocjonalnych w zespole, ma zarówno pozytywny, jak i negatywny wpływ na efekty dydaktyczne. Konieczność pogodzenia konkurujących celów jest czynnikiem zwiększającym kompetencje zespołowe i menedżerskie graczy, natomiast konflikt personalny działa destymulująco na indywidualne efekty kształcenia (Adobor i Daneshfar 2005).

\section{TWORZENIE MODELU PRZEDSIĘBIORSTWA NA POTRZEBY GRY BUDŻETOWEJ}

Celem omawianej w opracowaniu gry budżetowej jest symulacja roku działalności polskiego producenta i sprzedawcy kasków motocyklowych (integralnych, szczękowych i motocrossowych), motorowerowych półotwartych, narciarskich oraz rowerowych. Rozgrywka obejmuje planowanie działalności, tworzenie budżetów cząstkowych i głównego, kontrolę ich wykonania oraz wprowadzanie na bieżąco działań korygujących. Gra składa się z 48 rund - po 4 w 12 miesiącach roku.

Model logiczny leżący u podstawy gry zaprezentowano na ryc. 1. Na grę składają się 4 obszary, w których gracze będą podejmować decyzje; są to: polityka cenowa, polityka kadrowa, działania marketingowe i negocjacje zakupowe. Obszary te mają łącznie 10 punktów stycznych z modelem. Gracz musi kontrolować wykonanie planów (budżetów) ujętych w 7 zestawieniach. Największą złożoność modelu przewidziano w przypadku ilościowego planu sprzedaży, na który składa się 6 komponentów. Dla zapewnienia niepowtarzalności rozgrywki, oprócz losowości, której poziomem można sterować, istnieje również 10 innych parametrów modelu, w tym kilka o większym stopniu uszczegółowienia. Parametry te prowadzący zajęcia może ustawić przed przystąpieniem do rozgrywki. Należy zaznaczyć, iż gra może być prowadzona na 3 poziomach trudności, które determinują skalę wyzwań stojących przed studentem, łącznie w 8 obszarach gry. Domyślny poziom gry to poziom średni (nazwany „księgowa”). Wybór poziomu łatwiejszego („stażysta”) powoduje, że o 10\% zostaną wzmocnione efekty korzystnych decyzji gracza, zaś skutki decyzji niekorzystnych zostaną zredukowane o 10\%. Na poziomie trudniejszy (o nazwie „controller”) efekty korzystnych decyzji są zredukowane o 10\%, zaś zwiększone o $10 \%$ są skutki niekorzystnych wyborów. 


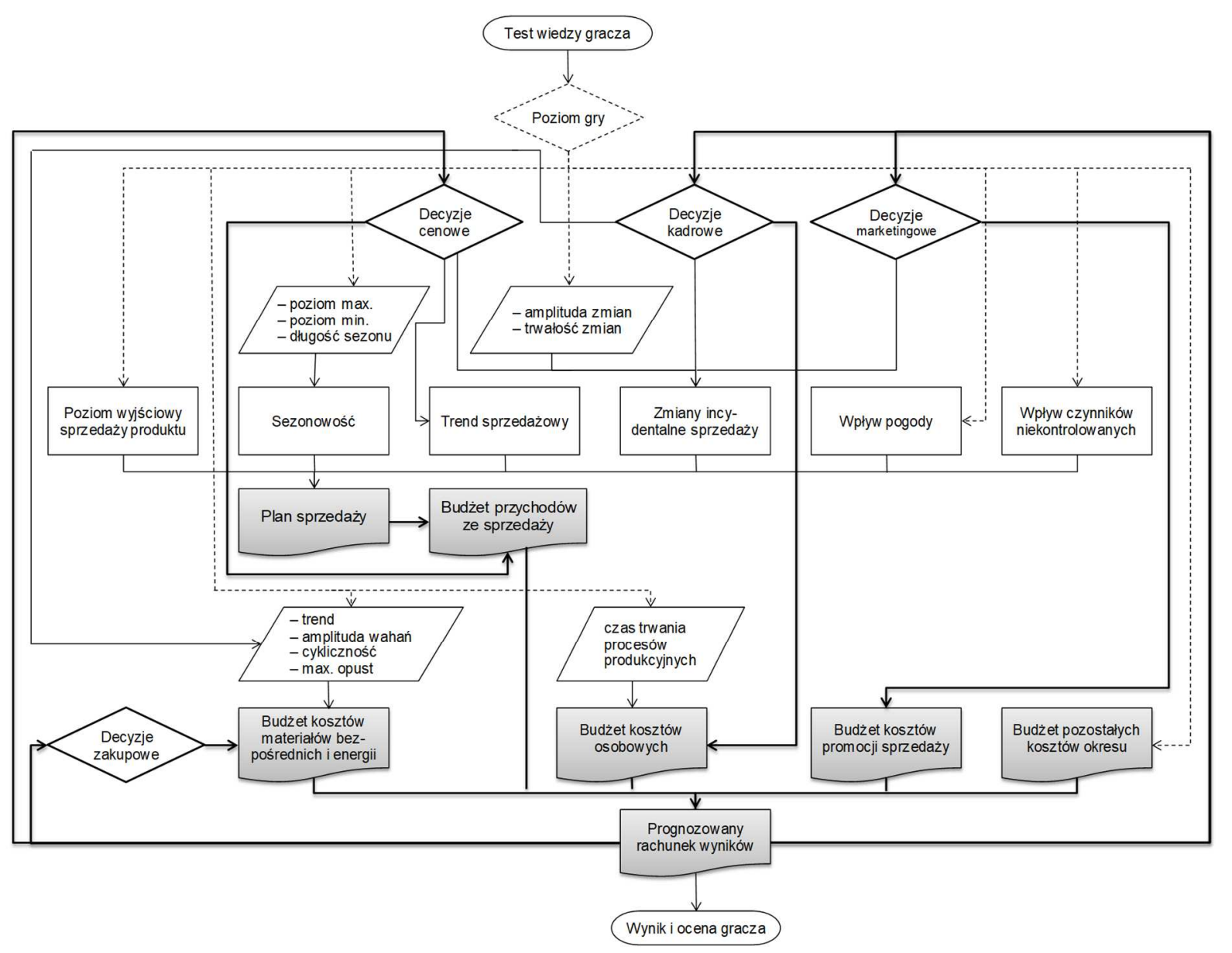

Ryc. 1. Model symulatora odchyleń budżetowych

W kolejnych podrozdziałach zostaną omówione zasady działania modelu w 3 najważniejszych obszarach decyzyjnych, tj. w sterowaniu sprzedażą, sterowaniu zamówieniami materiałowymi oraz w sterowaniu rozwojem kadr. Zrozumienie tych zasad ma kluczowe znaczenie dla poprawnej interpretacji wyników symulacji rozgrywki, zaprezentowanych w rozdziale trzecim pod kątem realizacji celów dydaktycznych przedmiotu controlling.

\section{STEROWANIE SPRZEDAŻA}

Kluczowym elementem symulatora odchyleń budżetowych jest plan sprzedaży, który wskazuje liczbę poszczególnych produktów możliwą do sprzedania w każdym okresie (rundzie gry). Ponadto wskazywana jest liczba partii produkcyjnych, które muszą być wcześniej wytworzone, aby sprostać popytowi. Ilościowy plan sprzedaży jest uzupełniony budżetem przychodów ze sprzedaży, który ujmuje przychody ze sprzedaży każdego produktu w poszczególnych okresach w sposób narastający oraz przychody ze sprzedaży ogółem.

Plan sprzedaży określonego produktu w danym okresie jest sumą 6 komponentów: stałego poziomu, trendu, sezonowości, zmian incydentalnych, wahań niekontrolowanych (pogody) oraz wahań losowych (czynników nieujawnionych). 
Stały komponent planu sprzedaży jest definiowany przez zmienną „wyjściowy poziom sprzedaży" i pozostaje niezmienny we wszystkich rundach gry.

Komponent trendu wynika z przyjętej strategii cenowej, a zatem z decyzji gracza co do ustalenia ceny sprzedaży poniżej, na równi albo powyżej ceny wyjściowej danego produktu. Dostępnych jest 5 poziomów trendu: silny wzrost, wzrost, bez zmian, spadek oraz silny spadek, zróżnicowanych na poszczególnych poziomach gry.

Komponent sezonowości bazuje na rozkładzie normalnym prawdopodobieństwa, dla którego zdefiniowano 4 parametry: wartość oczekiwaną (okres wystąpienia szczytu sprzedaży), poziomy maksymalny i minimalny (różnicę między sprzedażą w sezonie i poza nim) oraz odchylenie standardowe (długość trwania sezonu).

Komponent incydentalny obejmuje sumę efektów pozytywnych i negatywnych wywołanych zmianami o charakterze krótkotrwałym, będących następstwem działań samego przedsiębiorstwa (np. promocji sprzedaży) lub podmiotów w jego otoczeniu (np. wprowadzeniem nowych produktów do oferty przez konkurencję). Dla każdej zmiany incydentalnej określono trwałość efektu, oznaczającą część wzrostu lub spadku sprzedaży, która przechodzi do kolejnego okresu. Efekty zmian incydentalnych zależą również od ich typu, określonego jednym z 6 poziomów: duża szansa, średnia szansa, mała szansa, mały problem, średni problem, duży problem. Poszczególne zmiany incydentalne mogą oddziaływać na wszystkie grupy produktów lub tylko na kaski motocyklowe, narciarskie albo rowerowe. Część zmian może wystąpić w każdej rundzie gry, inne są ograniczone do węższych zakresów czasowych (np. udział w targach motocyklowych jest możliwy tylko w okresach, w których takie imprezy odbywają się w Polsce).

Istotnym parametrem zmian incydentalnych jest koszt podjęcia decyzji inicjowanych przez gracza (tj. kampanii marketingowych), który podlega wahaniom w ramach zdefiniowanego zakresu, co może wpłynąć na decyzję gracza o uruchomieniu danego działania. Dla zmian inicjowanych przez gracza ustalony jest również łączny budżet, który nie może zostać przekroczony w trakcie całej rozgrywki. Zmiany nieinicjowane przez gracza występują w danej rundzie ze zdefiniowanym prawdopodobieństwem.

Przedostatnim parametrem planu sprzedaży jest komponent niekontrolowany, który przyjmuje formę zmiennej pogodowej i wpływa na sprzedaż produktów letnich (kasków motocyklowych, motorowerowych i rowerowych) oraz zimowych (kasków narciarskich). O aktualnym poziomie komponentu niekontrolowanego gracz jest pośrednio informowany poprzez monitoring pogodowy, który prezentuje średnią temperaturę i prawdopodobieństwo opadów w danym tygodniu. W końcu istnieje komponent losowy, który zmienia się z rundy na rundę $\mathrm{w}$ dopuszczalnym zakresie wahań, w zależności od poziomu gry. O aktualnym poziomie komponentu losowego gracz nie jest informowany.

\section{STEROWANIE ZAKUPAMI MATERIAŁÓW}

W omawianym modelu przedsiębiorstwa cenę zakupu poszczególnych materiałów ustala się w drodze negocjacji na cały kolejny miesiąc (4 rundy). Istnieją 3 sposoby ustalania obowiązującej ceny. Pierwszą jest przedłużenie umowy na kolejny okres po znanej cenie „kup teraz". Drugim sposobem są negocjacje, które odbywają się w kolejnych rundach danego 
miesiąca, aż do uzgodnienia ceny. Podczas negocjacji gracz definiuje maksymalną cenę zakupu materiałów. Jeżeli cena ta mieści się w widełkach negocjacyjnych, umowa jest przedłużana. W przypadku fiaska negocjacji we wszystkich 4 rundach kontrakt jest automatycznie przedłużany po cenie z końca miesiąca, co wiąże się z ryzykiem wyższych kosztów zakupu materiałów w kolejnym okresie.

Widełki negocjacyjne ustalane są na podstawie kalkulacji aktualnej ceny materiału, według algorytmu uwzględniającego cenę bazową, trend, sezonowość, wahania cykliczne i komponent losowy. Ich dolna granica to minimum negocjacyjne, które nie jest znane graczowi. Minimum negocjacyjne zależy od aktualnej ceny oraz od maksymalnego opustu, który zależy od poziomu gry, a także od tego, czy gracz przeszkolił pracownika zaopatrzenia z technik negocjacyjnych. Trend wpływa na wzrost, stabilność lub spadek cen materiałów w roku, w zależności od wybranego poziomu trudności gry. Sezonowość definiuje zakres wahań cen materiałów w zależności od okresu roku. Komponent cykliczny określa zaś liczbę pełnych cykli wzrostów i spadków cen materiałów w skali całej rozgrywki, uzależnioną od wybranego poziomu gry.

\section{STEROWANIE ROZWOJEM KADR}

Ostatnim kluczowym obszarem decyzyjnym jest rozwój kadr. Gracz otrzymuje propozycje szkoleń, które podnoszą kompetencje poszczególnych pracowników i wpływają na niektóre parametry modelu w sposób oczekiwany przez gracza, ale w nieznanym przez niego stopniu. $\mathrm{Na}$ podstawie propozycji szkoleń jest tworzony ich plan. Tylko szkolenia przypisane do pracownika w ramach planu szkoleń będą mogły zostać zrealizowane w trakcie rozgrywki. Należy przy tym uwzględnić ograniczony budżet przedsiębiorstwa na szkolenia. W każdej rundzie gracz może sprawdzić, jaką część budżetu na szkolenia już wykorzystano.

Realizacja poszczególnych szkoleń wpływa na poziomy różnych zmiennych modelu, co gracz może zaobserwować pośrednio na podstawie zmian w przychodach ze sprzedaży lub w kosztach zużycia materiałów. Szkolenia pracowników wydziału produkcji z obszaru zarządzania jakością obniżają prawdopodobieństwo wystąpienia negatywnych opinii o produktach, niskich ocen w testach konsumenckich oraz wykrycia wadliwych produktów przez konsumentów. Zwiększa się natomiast szansa pojawienia się pozytywnych opinii o zakupionych produktach. Wskazane 4 zdarzenia to zmiany incydentalne wpływające na sprzedaż produktów. Szkolenie zaopatrzeniowca z zakresu technik negocjacji rozszerza widełki negocjacji cen materiałów. Natomiast każde szkolenie pracownika działu sprzedaży skutkuje wystąpieniem pozytywnej zmiany incydentalnej typu „średnia szansa”.

\section{WYNIKI SYMULACJI ROZGRYWKI I DYSKUSJA}

Jak wskazano w poprzednich częściach opracowania, testowanie symulatora budżetowego służy weryfikacji możliwości osiągnięcia wybranych celów kształcenia w ramach przedmiotu controlling i osiągnięciu efektów związanych z przekazaniem wiedzy, umiejętności oraz kompetencji. Warto zatem podkreślić, że symulator odchyleń budżetowych ma wspierać osiągnięcie dwóch celów dydaktycznych. 
Po pierwsze, jest to „przekazanie wiedzy i umiejętności dotyczących planowania i sterowania działalnością z wykorzystaniem takich metod i narzędzi controllingu, jak: budżetowanie, analizy odchyleń i zestawy wskaźników finansowych oraz niefinansowych". Realizacja pierwszego celu pozwala na osiągnięcie dwóch efektów dydaktycznych z obszaru wiedzy „zrozumienia procesu i poznania metod budżetowania w przedsiębiorstwie”, a także „dostrzeżenia znaczenia systemów informacyjnego wspomagania zarządzania organizacją".

Drugim celem dydaktycznym, wspieranym przez omawianą grę budżetową, jest „wykształcenie umiejętności samodzielnego prowadzenia analizy sytuacji ekonomicznej podmiotu, identyfikowania problemów oraz raportowania wniosków w przekonujący sposób”. Jego osiągnięcie powinno zaowocować następującymi efektami dydaktycznymi z obszaru umiejętności: „integracją planów rzeczowych i finansowych oraz tworzeniem budżetu”, „kontrolowaniem wykonania budżetów oraz ustalaniem przyczyny powstałych odchyleń”, „konstruowaniem wskaźników finansowych i niefinansowych oraz intepretowaniem w prawidłowy sposób osiąganych przez nie poziomów”, a także jednym efektem obszaru kompetencji, czyli „zdolnością argumentowania własnych poglądów oraz oceny poglądów innych, dotyczących problemów decyzyjnych wspomaganych przez controlling".

W celu walidacji przydatności omawianej gry budżetowej na potrzeby dydaktyki przedmiotu controlling wykonano ogółem 20000 symulacji rozgrywki, z wykorzystaniem algorytmów podejmujących decyzje, jakie musieliby podjąć prawdziwi gracze przy identycznych ograniczeniach. Tak duża liczba symulacji wynikała z faktu, iż decydenci w każdej z 48 rund gry mogli podjąć nawet 55 decyzji, co daje łącznie ponad 2500 decyzji w całej rozgrywce. Połowę rozgrywek przeprowadzono przy założeniu aktywnego sterowaniu sprzedażą i promocją sprzedaży przez graczy oraz wykorzystania przez nich możliwości negocjacji cen materiałów i prowadzenia szkoleń pracowników. Natomiast w pozostałej części rozgrywek przyjęto, że gracz pozostaje pasywny, nie ingerując w model, tylko obserwując wyniki. Ponadto oba typy rozgrywki przeprowadzono na 3 poziomach trudności gry (każdy rozegrany 3333 razy). Tak przeprowadzona walidacja modelu powinna przede wszystkim wskazać, jakie potencjalne korzyści uzyskają gracze aktywni wobec pasywnych oraz z jaką skalą wyzwania zmierzą się uczestnicy rozgrywek na 3 poziomach trudności. Podstawowe wyniki symulacji zaprezentowano w tab. 1.

Jak można zauważyć, gra została sparametryzowana poprawnie. Kolejne poziomy trudności stanowią większe wyzwanie dla graczy, zaś strategia aktywna jest bardziej opłacalna od pasywnej. Jeśli chodzi o średnie przychody ze sprzedaży w wariancie aktywnej gry, poziom: księgowa zapewnia $72,8 \%$, a poziom: controller - $52,5 \%$ wyniku poziomu: stażysta. Biorąc pod uwagę stopę rentowności sprzedaży, jest to odpowiednio $54,0 \%$ oraz $-12,4 \%$. Dodatkowo rozrzut możliwych do uzyskania wyników dla kolejnych poziomów trudności jest znacznie wyższy. W przypadku stopy rentowności sprzedaży wynosi od $21,2 \%$ wyniku średniego dla poziomu: stażysta, przez 65,9\% dla poziomu: księgowa, aż do $482,4 \%$ dla poziomu: controller. Zatem na kolejnych poziomach trudności wynik końcowy w znacznie większym stopniu zależy od decyzji graczy. W przypadku poziomu: controller jedynie najlepsi studenci są w stanie uzyskać pozytywny wynik finansowy. Ponadto na kolejnych poziomach gry pasywni gracze są w coraz większym stopniu „karani” za błędy i zaniechania. Biorąc pod uwagę stopę rentowności sprzedaży, „pasywny stażysta” uzyska średnio 15,5\% gorszy wynik niż jego „aktywny” odpowiednik, „pasywna księgowa” - już o 33,8\%, zaś „pasywny controller” musi liczyć się z niemal 3-krotnie gorszym rezultatem. 
Tabela 1. Oszacowane parametry modelu dla różnych wariantów gry

\begin{tabular}{|c|c|c|c|c|c|c|c|}
\hline \multirow{3}{*}{\multicolumn{2}{|c|}{ Parametry symulacji }} & \multicolumn{6}{|c|}{ Typ gracza } \\
\hline & & \multicolumn{3}{|c|}{ aktywny } & \multicolumn{3}{|c|}{ pasywny } \\
\hline & & minimum & średnia & maksimum & minimum & średnia & maksimum \\
\hline \multirow{3}{*}{$\begin{array}{l}\text { Przychody ze } \\
\text { sprzedaży [zł] }\end{array}$} & stażysta & 12779128 & 14638705 & 16342481 & 11602445 & 12341623 & 12908487 \\
\hline & księgowa & 9219657 & 10658895 & 12141519 & 8463783 & 9167750 & 9642289 \\
\hline & controller & 6740646 & 7679522 & 8508744 & 6166016 & 6762584 & 7198674 \\
\hline \multirow{3}{*}{$\begin{array}{l}\text { Koszty zużycia } \\
\text { materiałów } \\
\text { i energii [zł] }\end{array}$} & stażysta & 6406270 & 7333294 & 8161796 & 5874333 & 6250923 & 6526766 \\
\hline & księgowa & 4711041 & 5430444 & 6171294 & 4375705 & 4743144 & 4992934 \\
\hline & controller & 3492222 & 3971848 & 4392248 & 3253343 & 3558592 & 3772025 \\
\hline \multirow{3}{*}{$\begin{array}{l}\text { Koszty osobowe } \\
\text { [zł] }\end{array}$} & stażysta & 2492304 & 2547175 & 2657871 & 2471039 & 2477012 & 2481430 \\
\hline & księgowa & 2469258 & 2523573 & 2669414 & 2464358 & 2464358 & 2464358 \\
\hline & controller & 2470108 & 2509315 & 2595861 & 2464358 & 2464358 & 2464358 \\
\hline \multirow{3}{*}{$\begin{array}{l}\text { Koszty promocji } \\
\text { sprzedaży [zł] }\end{array}$} & stażysta & 18496 & 169449 & 299919 & 0 & 0 & 0 \\
\hline & księgowa & 16261 & 170673 & 299983 & 0 & 0 & 0 \\
\hline & controller & 9154 & 173142 & 299322 & 0 & 0 & 0 \\
\hline \multirow{3}{*}{$\begin{array}{l}\text { Pozostałe koszty } \\
\text { okresu [zł] }\end{array}$} & stażysta & 1140096 & 1200300 & 1259947 & 1140015 & 1200220 & 1259895 \\
\hline & księgowa & 1140019 & 1199199 & 1259913 & 1140002 & 1200472 & 1259993 \\
\hline & controller & 1140005 & 1200982 & 1259967 & 1140049 & 1200732 & 1259920 \\
\hline \multirow{3}{*}{ Wynik brutto [zł] } & stażysta & 2632867 & 3388487 & 4103604 & 1996444 & 2413468 & 2714107 \\
\hline & księgowa & 663089 & 1335005 & 1824553 & 400608 & 759776 & 1011634 \\
\hline & controller & -671177 & -175764 & 129876 & -760948 & -461098 & -245015 \\
\hline \multirow{3}{*}{ Wynik netto [zł] } & stażysta & 2132622 & 2744675 & 3323920 & 1617120 & 1954909 & 2198427 \\
\hline & księgowa & 537102 & 1081354 & 1477888 & 324493 & 615419 & 819424 \\
\hline & controller & -671177 & -176103 & 105199 & -760948 & -461098 & -245015 \\
\hline \multirow{3}{*}{$\begin{array}{l}\text { Stopa } \\
\text { rentowności } \\
\text { sprzedaży [\%] }\end{array}$} & stażysta & 16,43 & 18,73 & 20,41 & 13,94 & 15,83 & 17,07 \\
\hline & księgowa & 5,83 & 10,12 & 12,50 & 3,83 & 6,70 & 8,54 \\
\hline & controller & $-9,96$ & $-2,33$ & 1,28 & $-12,14$ & $-6,85$ & $-3,44$ \\
\hline
\end{tabular}

Warto również dodać, iż gra przewiduje możliwość uzyskania gorszego wyniku w przypadku gry aktywnej, niż gdyby gracz obserwował jedynie rozwój sytuacji. Jest to jednak mało prawdopodobne, gdyż oznaczałoby podejmowanie w większości błędnych decyzji. Oczywiście błędy w przypadku poziomu: controller są bardziej dotkliwe, dlatego wyjątkowo szczęśliwy obserwator uzyska poziom ROS $-3,44 \%$, podczas gdy bardzo nieefektywny aktywny gracz może odnotować ROS nawet na poziomie -9,96\%. Szczęście jest ważne w biznesie, ale w zdecydowanej większości przypadków nie zastąpi rzetelnej analizy, co widać na wykresach (ryc. 2).

Na podstawie wykresów (ryc. 2) można wyznaczyć oczekiwane poziomy wyników rozgrywki dla odpowiedniego procenta populacji grających. Centyle 50-90 mogą być uznane za wyniki oczekiwane od studentów, którzy aspirują do poszczególnych ocen pozytywnych. Centyle 0-1 i 99-100 pokazują natomiast sytuacje ekstremalne, które wskazują na wyjątkowo nieuzdolnionych graczy lub urodzonych controllerów. Warto zauważyć, że wraz z rosnącym poziomem trudności wymagane będzie zwrócenie uwagi na coraz mniejsze wartości odchyleń, które będą miały istotny wpływ na wynik końcowy. Oczywiście autorzy nie zamierzają opierać oceny z przedmiotu wyłącznie na wyniku gry. Jednak sam fakt, że będzie miał on wpływ na ocenę, powinien skłonić studentów do większego zaangażowania w rozgrywkę, zapewniając realizację założonych celów dydaktycznych. 

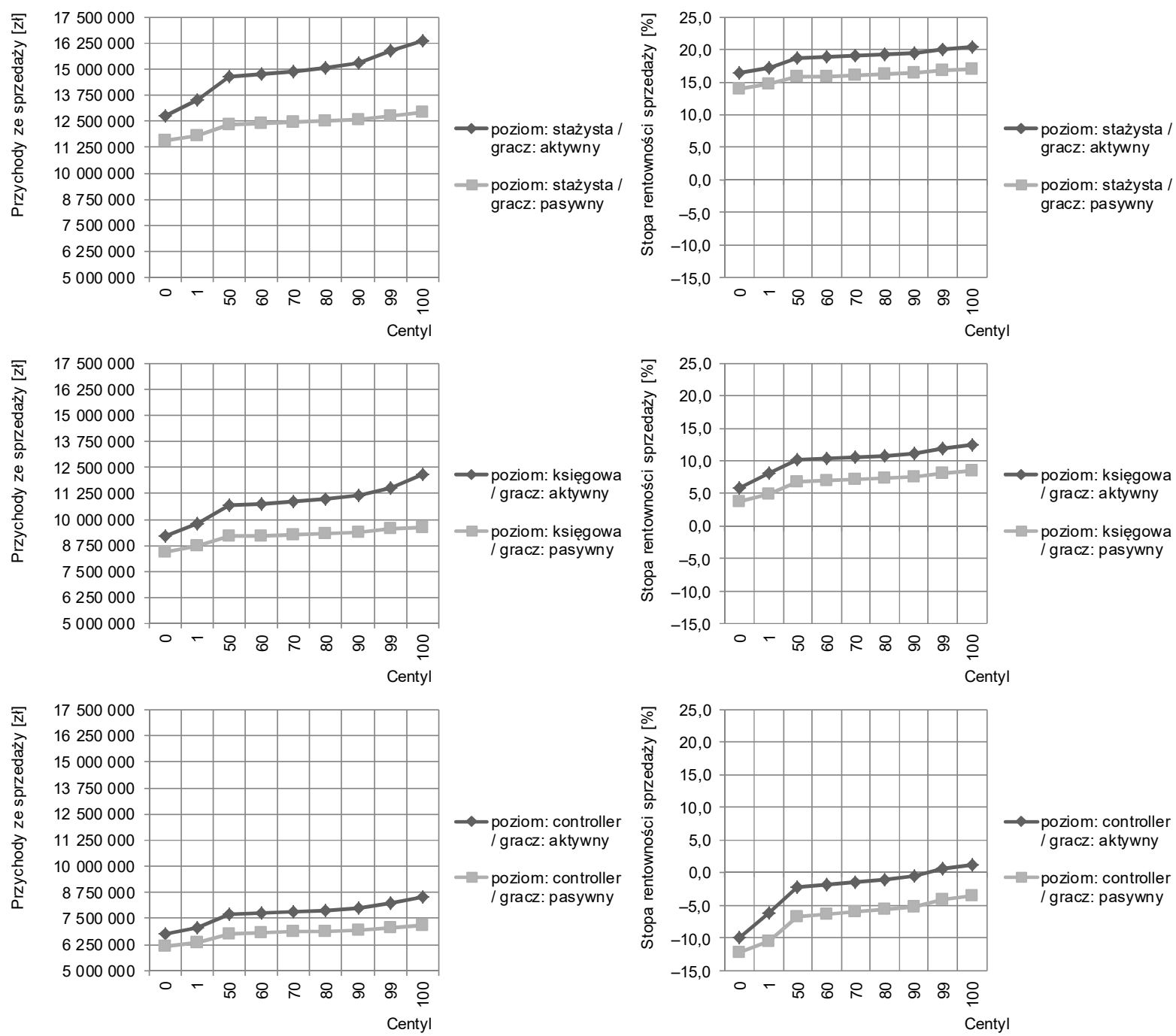

Ryc. 2. Symulacja wyników gry w jej różnych wariantach

Podsumowując wyniki symulacji rozgrywki, należy zauważyć, że istotną przewagą gier biznesowych nad zadaniami - bez względu na poziom złożoności i realizmu tych ostatnich jest uwzględnienie elementu nieprzewidywalności. Współczesne programy nauczania w bardzo dobrym stopniu przekazują studentom umiejętności rozwiązywania problemów deterministycznych. Jednak w znacznie mniejszym zakresie kształcą kompetencje otwartego myślenia i reagowania na nieprzewidywane zmiany w otoczeniu biznesowym. Umiejętność kreatywnego działania jest niezbędna w złożonym i dynamicznym środowisku gospodarczym (Eickhoff i in. 2014), i musi być objęta kształceniem (Dyczkowski 2012). Występująca w przypadku omawianego symulatora odchyleń niepowtarzalność rozgrywki powoduje, że studenci nie mogą zadowolić się osiągniętym po kilku rundach poziomem wyników, ale muszą ustawicznie korygować swoje działania, obserwując bieżące odchylenia od planu. Ponieważ wynik gry będzie uwzględniony przy ocenie studenta z przedmiotu, stanie się możliwe postulowane przez Kesa (2014) wywołanie na graczu presji, która towarzyszyłaby zarządzającym i controllerom w realnym przedsiębiorstwie, gdy założony plan nie jest realizowany i gdy występują niekorzystne odchylenia.

Nie można ponadto zignorować faktu, że przedmioty z obszaru rachunkowości są ogólnie postrzegane przez studentów jako użyteczne, ale mało atrakcyjne. Wykorzystując mieszane techniki dydaktyczne, prowadzący dają studentom swobodę wyboru tej metody nauki, która 
pozwoli im najlepiej zrozumieć podstawowe zagadnienia z przedmiotu i pokaże ich związki $z$ innymi problemami ekonomicznymi i finansowymi, co ma kluczowe znaczenie w motywacji do dalszego zdobywania wiedzy (Jaijairam 2012).

\section{PODSUMOWANIE}

Wprowadzenie gier do dydaktyki rachunkowości zarządczej i controllingu nie powinno być postrzegane jako uatrakcyjniający zajęcia „fajerwerk”, który mimochodem pozwala na poznanie prostych zasad funkcjonowania przedsiębiorstwa. Jest to działanie służące poszerzeniu zakresu kształconych kompetencji o pracę zorientowaną na realizację planu, działanie w warunkach niepewności lub ryzyka oraz współpracę w zespole.

W tym kontekście należy uznać, że przeprowadzona walidacja modelu gry symulacyjnej udowodniła jego przydatność w realizacji celów dydaktycznych przedmiotu controlling. Dodatkowym atutem gry jest jej wszechstronność i elastyczność wynikające z dostępnych poziomów trudności, szerokiego zakresu podejmowanych przez graczy decyzji i z elementów losowych. Najniższy poziom gry (stażysta) pozwala na zapoznanie się z procesem budżetowania i kształci umiejętność interpretacji odchyleń, przy ograniczonych konsekwencjach złych wyborów. Na poziomie: księgowa student w celu dokonywania trafnych wyborów powinien zdobyć umiejętność analizy wpływu poszczególnych czynników (zależnych i niezależnych od decydentów) na wyniki przedsiębiorstwa. Rosnąca skala wyzwania utrudnia przy tym odrobienie strat wynikających z błędów lub zaniechań. Poziom: controller, na którym każdy błąd i nieoptymalna decyzja skutkuje niemożnością osiągnięcia pozytywnego wyniku, uczy radzenia sobie z presją wyniku, śledzenia i analizy wszystkich odchyleń, rozważania ryzyka i wybierania momentu podejmowania decyzji lub wstrzymania się z decyzją w przypadku niekorzystnych uwarunkowań rynkowych.

Autorzy mają nadzieję, że implementacja gry podczas zajęć z controllingu pozwoli na sformułowanie wniosków dotyczących faktycznej efektywności tego narzędzia w dydaktyce rachunkowości.

\section{PIŚMIENNICTWO}

Adobor H., Daneshfar A. 2005. Management Simulations: determining their effectiveness. J. Manag. Develop. 25(2), 151-168.

Bruns W.J. Jr. 1965. Business games in accounting instruction. The Account. Rev. 40(3), 650-653.

Cronan T.P., Douglas D.E., Alnuaimi O., Schmidt P.J. 2011. Decision making in an integrated business process context: Learning using an ERP simulation game. Dec. Sci. J. Innov. Educat. 9(2), 227-234.

DeCostner D., Prater G. 1973. An experimental study of the use of a business game in elementary accounting. The Account. Rev. 48(1), 137-142.

Dyczkowska J. 2012. Udział doktorów w realizacji i rozwoju oferty dydaktycznej Katedry Controllingu, w: Doktor niejedno ma imię. Red. A. Kardasz. Wrocław, Wydaw. UE.

Dyczkowski T. 2012. Uczyć kreatywności, ucząc kreatywnie. Doświadczenia projektu Competence in EuroPreneurship (COEUR)/Business Creativity Module (BCM), w: Doktor niejedno ma imię. Red. A. Kardasz. Wrocław, Wydaw. UE. 
Eickhoff M., Trigo V., Turnbull A., Dyczkowski T. 2014. COEUR - Developing business creativity and Europreneurship in European University Networks. J. Adv. Higher Educat. 6(1), 76-101.

Huang Ch.-W., Hsu Ch.-P. 2011. Using online games to teach personal finance concepts. Am. J. Bus. Educat. 4(12), 33-38.

Jaijairam P. 2012. Engaging accounting students: How to teach principles of accounting in creative and exciting ways. Am. J. Bus. Educat. 5(1), 75-78.

Kes Z. 2014. Gry ekonomiczne w nauczaniu budżetowania. Pr. Nauk. UE Wroc. 335, 93-104.

Kotapski R. 2012. Nauka i praktyka a dydaktyka, w: Doktor niejedno ma imię. Red. A. Kardasz. Wrocław, Wydaw. UE.

Michel M., Farrelly A., Basoglu B. 2013. Enriching undergraduate managerial accounting with a brief budget simulation game. J. Bus. Educat. Lead. 4(1), 139-147. 
